\title{
FISH ASSEMBLAGE PATTERNS ACROSS A GRADIENT OF FLOW REGULATION IN AN AUSTRALIAN DRYLAND RIVER SYSTEM
}

\author{
Stephen R. Balcombe ${ }^{\mathrm{AD}}$, Angela H. Arthington ${ }^{\mathrm{A}}$, Martin C. Thoms ${ }^{\mathrm{B}}$ and G. Glenn \\ Wilson $^{\mathrm{C}}$ \\ A eWater Cooperative Research Centre, Australian Rivers Institute, Griffith \\ University, Nathan, Qld, 4111, Australia.
}

${ }^{\mathrm{B}}$ Riverine Landscapes Research Lab, University of Canberra, ACT 2601, Australia

${ }^{\mathrm{C}}$ Ecosystem Management, School of Environmental and Rural Science, University of New England, Armidale, NSW 2351, Australia

${ }^{\mathrm{D} C o r r e s p o n d i n g ~ a u t h o r . ~ E m a i l: ~ s . b a l c o m b e @ g r i f f i t h . e d u . a u ~}$

\begin{abstract}
Hydrological regime, physical habitat structure and water chemistry are interacting drivers of fish assemblage structure in floodplain rivers throughout the world. In rivers with altered flow regimes, understanding fish assemblage responses to flow and physico-chemical conditions is important in setting priorities for environmental flow allocations and other river management strategies. To this end we examined fish assemblage patterns across a simple gradient of flow regulation in the upper MurrayDarling Basin, Australia. We found clear separation of three fish assemblage groups that were spatially differentiated in November 2002, at the end of the winter dry season. Fish assemblage patterns were concordant with differences in water chemistry, but not with the geomorphological attributes of channel and floodplain waterholes. After the summer-flow period, when all in-channel river sites received flow, some floodplain sites were lost to drying and one increased in volume, fish assemblages were less clearly differentiated. The fish assemblages of river sites did not increase in richness or abundance in response to channel flow and the associated potential for increased fish recruitment and movement associated with flow connectivity. Instead, the more regulated river's fish assemblages appeared to be under stress, most likely from historical flow regulation. These findings have clear implications for the management of hydrological regimes and the provision of environmental flows in regulated rivers of the upper Murray-Darling Basin.
\end{abstract}

KEY WORDS: geomorphology, water chemistry, fish assemblage structure, environmental flows

\section{INTRODUCTION}

Water resource development in many of the world's floodplain rivers has led to changes in fish diversity, community structure and productivity, and assisted the establishment of exotic species (Rodriguez and Lewis 1997; Bunn and Arthington, 2002; Welcomme et al., 2006). The Murray-Darling Basin (MDB), Australia's largest catchment (with an area of $1.06 \mathrm{mkm}^{2}$ ) is no exception with most of its rivers altered since the 1960s by dams and water abstraction to support agricultural and rural 
50 development (Arthington, 1996; Thoms et al., 2005). Fish stocks of Murray-Darling Basin rivers have been documented as severely stressed and in decline as a result of river regulation (Walker and Thoms, 1993; Gehrke et al., 1995; MDBC, 2004).

In the northern MDB, rainfall and runoff are highly variable and unpredictable such that many rivers exist as strings of disconnected waterholes apart from times of irregular flow. The impacts of water resource development on aquatic biota, especially fish assemblages, are likely to be severe in these dryland river systems (Davies et al., 1994; Kingsford, 2006). Fish living in dryland rivers maintain populations through prolonged "bust" periods by means of resistance traits and lowflow recruitment processes (Arthington et al., 2005; Balcombe and Arthington, 2009). Given that water resource development and allocation to irrigated agriculture tends to remove low flow pulses (Bunn et al., 2006), the potential for fish populations and assemblages to recover during "boom" conditions may be limited if they do not retain sufficient numbers to take advantage of higher flow conditions. Furthermore, changed natural patterns of flow, and hence connectivity potential among waterholes, are likely to limit the resistance of fish to low flow disturbances and also their resilience, as they rely on connectivity among waterholes to maintain populations through movement and recruitment processes (Junk et al., 1989; Puckridge et al., 2000; Balcombe et al., 2006; 2007; Balcombe and Arthington, 2009).

In order to manage these altered river systems by strategies such as the

70 allocation of environmental flows, it is important to understand the main drivers of fish distribution and abundance patterns, especially the significance of modified flow regimes (Arthington et al., 2006; Welcomme et al., 2006; Poff et al., 2009). To this end, we compared fish assemblages across 15 waterholes within the Border Rivers, Moonie River and Barwon River catchments of the northern MDB that were grouped a priori based upon antecedent hydrology and levels of hydrological alteration. Our primary hypothesis was that waterhole geomorphology interacting with hydrological conditions and water chemistry (cf. Arthington et al., 2005; Balcombe et al., 2006) would be the primary drivers of differences in fish abundance, species richness and assemblage structure across the gradient of flow regulation.

\section{MATERIALS AND METHODS}

Waterholes were located on the floodplains and within the channel of the MacintyreBarwon River and in-channel of the Moonie and Weir Rivers. The Macintyre and Barwon Rivers are subject to highly regulated river flows via a number of impoundments upstream of Goondiwindi which regulate $88 \%$ of inflows (CSIRO, 2007). Water storage in impoundments has decreased the average frequency of flows that connect anabranches and billabongs of the Macintyre river floodplain by about 22 percent and has reduced the volume of individual events by about 8 percent (CSIRO, 2007). Furthermore, Thoms et al., (2005) report that three headwater dams and 15 main channel weirs in the Macintyre catchment have significantly reduced the mean annual flow volume of the Macintyre River by as much as 38.5\% at Goondiwindi.

In contrast, river flows in the much smaller Moonie and Weir Rivers remain unregulated by large storage impoundments, and contain comparatively fewer weir structures (Biggs et al., 2005). In these two catchments existing surface water extraction are small, and at present, groundwater development is considerably lower in comparison to the Macintyre and Barwon systems (Biggs et al., 2005). The low 
level of water resource development in the Moonie and Weir Rivers differentiates them from the much larger and heavily impacted Macintyre and Barwon Rivers.

Waterholes were selected to represent the natural range of size, shape, connectivity and water permanence throughout the Barwon catchment by selecting up to four waterholes in four regions (Goondiwindi, Talwood, Mungindi and Collarenebri) of this catchment (Fig. 1). Four waterholes were studied in the first three regions, although only three were included at Collarenebri due to the loss of one waterhole to drying prior to our first sampling occasion. All fifteen waterholes were sampled for fish in November 2002 and thirteen were sampled in April 2003, due to the loss of a further two waterholes through drying. Waterholes included main channel regulated river sites (the Barwon or Macintyre River, BAR), smaller, unregulated river channel sites (the Weir or Moonie Rivers, MW) and floodplain sites (waterholes on the Barwon/Macintyre floodplain, FP).

Thirty-four physical floodplain and waterhole variables were measured in November 2002 at three spatial scales (Table I) using remote aerial photography or on ground surveying for each of the fifteen waterholes. The definition and collection of these variables was based on methods developed by Parsons et al., (2004) and elaborated in Arthington et al., (2005). Water samples were collected from the surface at each site and analysed in the laboratory for ionic composition and nutrient concentration following standard methods (APHA 1975). Water chemistry was analysed on the two fish sampling occasions: November 2002 and March 2003.

The fish assemblage within each of the fifteen waterholes was sampled using three fyke nets and a single beach seine. Fyke wing width and sampling duration were recorded for each net for the subsequent calculation of catch per unit effort (CPUE), where CPUE represents the sum total of individuals collected from three fyke nets set for $19 \mathrm{~h}$ with the wing entrance $10 \mathrm{~m}$ in width and one seine haul standardised to a $50 \mathrm{~m}^{2}$ area. Fyke nets (13 mm mesh) captured both small and largebodied individuals of all species. Fish were identified and counted and all native species were returned live to the water at the point of capture.

\section{Data Analysis - geomorphology and water chemistry}

130 Similarities and differences in waterhole geomorphology and water chemistry were analysed using ordination based upon hybrid non-metric multi-dimensional scaling (MDS). MDS plots were generated from Normalised Euclidean distance similarity matrices produced from $\log _{10}(\mathrm{x}+1)$ abundance and species presence/absence data. One-way analyses of similarities (ANOSIM), based upon the same similarity

135 matrices, were used to identify differences among the three waterhole groups (BAR, MW and FP) in relation to their geomorphology and water chemistry.

Geomorphological features were measured and analysed for one occasion only, November 2002, at two spatial scales: macro-scale (landscape and whole waterhole) features and meso-scale (within waterhole) features (Table I).

Univariate analysis of fish abundance and richness

Variations in fish species presence/absence and assemblage structure across waterholes and sampling times were analysed using the combined fyke and seine net CPUE data. These CPUE data were also used as a measure of total fish abundance (all species) and the abundance of individual species per waterhole. Species richness for each waterhole was based upon the data collected by both sampling methods. Oneway analysis of variance (ANOVA) was used to test the predictions that waterhole group (fixed factor) influences total fish CPUE and species richness amongst 
waterholes for each of the two sampling occasions. To meet the assumptions of ANOVA all CPUE data were normalised by $\log _{10}(\mathrm{x})$ transformations; these transformations also improved homogeneity of variances among waterhole groups. Statistical significance was accepted at $P \leq 0.05$. Tukeys HSD post-hoc tests were used to establish the nature of any differences in CPUE or species richness among each possible pair of waterhole groups.

Multivariate analysis of fish abundance and richness

Fish species CPUE and presence/absence data were analysed using SIMPER to identify the main species driving differences in each waterhole group for each of the two sampling times. Assemblage patterns were subsequently analysed using ordination based upon hybrid non-metric multi-dimensional scaling (MDS). MDS plots were generated from Bray-Curtis similarity matrices produced from $\log _{10}$ (CPUE +1 ) and species presence/absence data. One-way analyses of similarities (ANOSIM) based upon the same similarity matrices were used to identify assemblage differences among the three waterhole groups (Barwon River, BAR; Moonie/Weir River, MW;

165 floodplain, FP) during the November 2002 and March 2003 sampling occasions. SIMPER was used to describe the main species contributing to differences among each pairwise comparison.

BIO-ENV (Clarke and Warwick, 2001) was used to investigate relationships between physical characteristics of the landscape (i.e. floodplain features), waterhole

170 characteristics, water chemistry and fish assemblage structure/richness. BIO-ENV uses generalised Mantel tests to examine associations between faunal datasets and environmental data, expressed as Spearman rank correlation coefficients for the association between the two matrices (Clark and Ainsworth, 1993). Autocorrelated floodplain and waterhole variables were removed prior to the BIO-ENV procedure,

175 using Spearman rank correlations $\left(\mathrm{r}_{\mathrm{s}}>0.8\right)$ to identify redundant variables. The environmental similarity matrices were based upon normalised Euclidean distance rather than Bray-Curtis similarity as per Clarke and Warwick, (2001). BIO-ENV analysis was performed on the November 2002 and March 2003 datasets. All multivariate analyses were undertaken in the PRIMER version 5 software package

180 (Clarke and Gorley, 2001).

Associations between individual species and water chemistry parameters were examined using Spearman rank correlation. Due to the large number of tests undertaken, significant correlations were accepted at $p<0.001$ to protect against Type I error (Keppel, 1991). All univariate analyses were performed using Systat for

185 Windows 11.00.01 (SSI, 2004).

\section{RESULTS}

\section{Hydrology and water chemistry}

Prior to the first sampling occasion (November 2002), most waterholes were on a trajectory of decreasing volume as most had not received any inflows since March April 2002 (Figure 2). The exception to this was that the two Moonie River waterholes had received a $300 \mathrm{MLday}^{-1}$ flow in October 2002. All Macintyre and

195 Barwon River sites experienced periods of flow between the first and second (March 2003) sampling trips, hence they experienced channel connectivity among the main river sites. The two Weir River sites had a minor in-channel flow event approximately 
two weeks prior to sampling in March 2003, while a flow pulse was passing through the Moonie River sites at the time of sampling in March 2003.

Although there were no gauging stations at the floodplain sites, landholder information revealed that all floodplain sites had received water inputs during the autumn prior to the first sampling occasion in November 2002. After this time and prior to the second sampling occasion (March 2003), Punbougal Lagoon was the only floodplain site that had received any significant in-flow from local rains, resulting in water level retraction at Maynes and Wirrabilla Lagoons and Gnungarah Creek (Figure 2). Furthermore, this drying event resulted in the complete drying of two sites, Whalan Creek and Wolonga Lagoon, by the second sampling occasion in March 2003.

Water chemistry variables tracked the hydrological patterns and differences among waterholes, as indicated by high levels of conductivity and dissolved ions across most waterholes in November 2002 following the dry period (Table II). This trend was not apparent in the MW sites, particularly the two Moonie River sites, where low conductivity and dissolved ions and high turbidity were associated with the recent flows in the Moonie River. In contrast, FP sites were at the opposite extreme,

215 with low turbidity, high conductivity and dissolved ions. Water chemistry in BR sites sat in between the MW and FP sites, with intermediate values for most components measured.

The three waterhole groups formed three distinct water chemistry groups in multidimensional space (Figure 3a). MW and BAR waterholes formed distinct clusters, while FP sites comprised a looser aggregation (Figure 3a). ANOSIM revealed that water chemistry factors were significant in differentiating waterhole groups and pair-wise differences between the three waterhole groups were also significant (Table III).

In March 2003, water chemistry was generally less differentiated across sites

225 due to the effects of recent flows (Figure 3b). FP waterholes were particularly spread in ordination space, suggesting that each waterhole within the group changed along its own temporal trajectory. Even though BAR and MW sites had received inflows prior to March 2003, these two waterhole groups still sat apart and formed reasonably distinct groups in ordination space (Fig 3b). Waterhole chemistry was significantly

230 different in relation to waterhole group in March 2003, and all pair-wise comparisons were also significant (Table III).

\section{Geomorphology}

The 15 waterholes overlapped in their basic dimensions, although the Moonie and

235 Weir River (MW) waterholes tended to be smaller in area and volume than either the floodplain (FP) or the Barwon and Macintyre River (BAR) waterholes (Table II). FP waterholes also tended to be surrounded by a wider floodplain than the other two groups, while BAR waterholes tended to have the largest surface area of the three types.

240 Ordination of the macro-scale physical data revealed a broad spread of waterholes (Figure 4a). The only significant separation of waterhole groups was between the FP and MW sites (Fig 4a, Table III). Similarly, at the meso-scale, FP and MW waterholes formed relatively tight groups, without overlap, while BAR waterholes showed greater within-group variation (Figure 4b). Meso-scale physical

245 factors were significantly different in relation to waterhole group, and pair-wise comparisons revealed that only FP and BAR sites were significantly different to each other (Table III). 
Fish assemblages

We collected a total of 13 species across the 15 sites and two sampling occasions, comprising nine native species from eight families and three exotic species from two families (Table IV). Throughout the course of this study we recorded a total catch per unit effort of 2151 fish (Table V). Bony bream was the most abundant species, accounting for $68 \%$ of fish caught across all sites and sampling times. It was found in all waterholes sampled on at least one occasion and was most abundant in FP waterholes across both time periods. The next most abundant species were yellowbelly (11\%), carp gudgeons (10\%) and common carp (5\%). Of these three species, carp gudgeons were the least distributed across sites, being restricted mostly to FP sites, particularly Punbougal Lagoon where $81 \%$ of their total was captured.

260 Few yellowbelly were caught in floodplain sites, with the majority caught in MW sites. This pattern was also largely reflected in the distribution of common carp.

Total fish CPUE and species richness showed limited variability among the three waterhole groups in both sampling periods (Figure 5). In November 2002 after the dry period, CPUE was significantly different in relation to waterhole group

265 (ANOVA: $F_{2,12}=16.3$, Figure 5a). Tukey's pairwise comparisons revealed that FP waterholes had significantly higher CPUE than both BAR and MW waterholes. Although there was still a tendency for CPUE to be highest in FP waterholes compared to the other two groups (Figure 5b) in March 2003, there was no significant difference in CPUE in relation to waterhole group (ANOVA: $F_{2,12}=2.7$ ). In

270 November 2002, although species richness was generally lower in MW sites than others (Figure 5c), waterhole groups were not significantly different (ANOVA: $F_{2,12}=$ 3.7). In March 2003 there was a tendency for MW sites to have greater species richness than other sites (Fig 5d), although this difference was also non-significant (ANOVA: $\mathrm{F}_{2,12}=3.7$ ).

\section{Fish assemblage patterns}

SIMPER analysis revealed that similarities in fish assemblages within both FP and BAR sites based upon CPUE data were largely due to the abundance of bony bream, accounting for between 52 and 99\% of the similarity across sites and times (Table

280 VI). In contrast, the similarity among MW waterholes based upon CPUE was due to the abundances of yellowbelly and the exotic common carp and goldfish in November 2002 and yellowbelly, bony bream and common carp in March 2003 (Table VI).

Similarities in fish assemblages among waterhole groups based on species presence/ absence were less clear than for assemblages based on CPUE (Table VI)

285 with high variability in the species that accounted for most of the patterns. In November 2002, $72 \%$ of the similarity in BAR sites was due to the presence/absence of rainbowfish and yellowbelly while 6\% of the similarity in March 2003 was driven by bony bream and yellowbelly. Bony bream and carp gudgeon presence/absence had the greatest influence on FP site similarities (61\%) in November 2002, while in March

2902003 bony bream dominated the assemblage patterns (78\% similarity). MW site similarities were largely due to carp presence/absence in November 2002 (60\%), while in March 2003 presence/absence assemblage patterns were due to the combined patterns of five species (Table VI).

Ordination plots of fish assemblage structure based on CPUE revealed a clear separation of assemblages along the three waterhole groups (Figure 6). This was especially so in November 2002 when there were three clear assemblage groups. These patterns were also supported by ANOSIM, with fish assemblage structure 
significantly different across all pairs of groups (Table VII). SIMPER revealed that the differences in assemblage structure between FP and the other two waterhole groups were due largely to the high abundances of bony bream and, to a lesser extent, carp gudgeons in FP waterholes (Table VI and VII). In contrast, the difference in assemblage structure between MW and BAR waterholes was influenced by the abundances of a wider array of species: higher numbers of bony bream and rainbowfish in BAR waterholes, and more yellowbelly, carp and goldfish in MW waterholes.

In March 2003 some waterholes had received in-flows prior to sampling while others had decreased in volume since November 2002, hence, the fish assemblages in waterhole groups formed looser aggregations in multidimensional space than in November 2002 (Fig 6b). FP and BAR sites were particularly loosely arranged

310 towards the left half of the plot, while MW sites sat in the right half. While waterhole group was significant for overall fish assemblage structure, only MW sites were significantly different to the other two groups (Table VII). These differences in assemblage structure were largely due to the higher numbers of yellowbelly and lower numbers of bony bream in MW waterholes compared to the other two waterhole 315 groups (Tables VI and VII).

Patterns of assemblage structure based upon species presence/absence again revealed a strong and significant influence of waterhole group in November 2002 (Fig 7a; Table VII). MW sites formed a clear grouping to the right of the MDS plot, FP waterholes sat toward the top middle to left, while BAR sites tended to sit mid-bottom 320 of the plot. All pair-wise comparisons among waterhole groups were significant and these differences reflected a much more even spread of species than for the CPUE patterns, with at least seven species contributing to more than $82 \%$ of the pair-wise differences (Table VII). In addition to the common species found to influence CPUE assemblage patterns, the remaining species (such as spangled perch, carp gudgeons, 325 catfish and smelt) also contributed to the presence/absence assemblage patterns. In March 2003, fish assemblage patterns based upon species presence/absence were less clear than in November 2002, with sites largely spread within the MDS plot (Figure 6b). While all MW waterholes remained within a tight group, both FP and BAR waterholes followed separate trajectories and, hence, waterhole group was not a significant factor explaining patterns in assemblage structure (Table VII).

Bio-Env analysis revealed no concordance between fish assemblage structure and the geomorphological variables measured in November 2002. Some clear relationships were, however, apparent between fish ordination patterns and water chemistry variables. Turbidity was most consistently associated with spatial patterns 335 in fish CPUE (Table VIII). Fish species presence/absence patterns were less clear showing the strongest association with the three combined variables TC, $\mathrm{NO}_{3}$ and $\mathrm{SO}_{4}$ in November 2002, while the associations with water chemistry were weak in March 2003 (Table VIII).

While there was no association between geomorphological factors and fish 340 assemblage structure, there were significant correlations between some of these factors and individual species abundances (Table IX). For example, the abundance of M. ambigua was negatively correlated with both area (A) and wetted perimeter (WP) of waterholes on both sampling occasions. In addition to these results, there was also a consistent pattern of waterhole scale factors being correlated with fish species

345 abundance, with A, ACS (area of cross section) and WP being significantly correlated with one or more of bony bream, yellowbelly and common carp on both sampling occasions. Similarly, conductivity and turbidity were also consistently associated 
with the abundance of one or more of the same three fish species on both sampling occasions.

\section{DISCUSSION}

Fish assemblage structure in the waterbodies of large floodplain rivers can be predicted from hydrological, physical and water chemistry factors, particularly where these factors vary predictably from year to year (Junk et al., 1989; Rodriguez and Lewis, 1997). This predictability is important when floodplain rivers are regulated and it becomes desirable to recommend environmental water allocations that will enhance and restore fish populations and assemblages (Welcomme et al., 2006). In highly variable river systems, our capacity to predict fish assemblage and population characteristics is more problematic, and exacerbated when flow regimes are regulated. Yet, the search for patterns of ecological response to flow regime change is essential to support environmental flow management (Poff et al., 2009). In this study, we sought to identify the main drivers of fish assemblage and abundance patterns across a simple gradient of flow regulation in three dryland floodplain rivers.

The physical attributes of the fifteen waterholes were highly variable and did not separate strongly into distinctive groups. The Moonie, Weir, Macintyre and Barwon River waterholes were most similar and could not be differentiated at either of the two spatial scales of physical assessment (large scale and within waterhole scale). If physical features of waterholes were key drivers of fish distribution and abundance patterns then we would expect that the fish assemblages of MW and BAR waterholes would be most similar, and FP assemblages to be differentiated from the other two types. However, the three waterhole groups were more strongly differentiated by their water chemistry, in both November 2002 and March 2003. Hence, if water chemistry was a key driver of fish assemblage attributes then we would expect the three waterhole groups to have strongly differentiated fish assemblages on both sampling occasions.

Total abundance and species richness of fish assemblages did not meet our predictions in relation to the three waterhole groups, with little variability evident

380 apart from FP waterholes having higher fish abundances than either the MW and BAR waterholes in November 2002. Given the dominance of bony bream to total abundance in the catchment, and the low species richness (approx. four species on average per waterhole for all samples collected), these results are perhaps not so surprising. Bony bream is a habitat generalist and arguably the most widely 385 distributed Australian dryland fish species (Pusey et al., 2004). We would, therefore, not expect bony bream or total fish abundance to be particularly sensitive to habitat, hydrological or water chemistry differences among waterhole groups. While we detected 13 species in total, the low species richness in any one site would also reduce the likelihood of detecting large diversity differences among the waterhole groups.

390 The aspect of fish assemblages that should be more detectable across differing environmental conditions among waterhole groups would be differences in the actual species make-up and their relative abundances (Arthington et al., 2005; Balcombe et al., 2006).

By contrast, fish assemblage structure did show significant differences among 395 waterhole groups, as predicted, particularly in November 2002. At that time, the three waterhole groups were significantly differentiated in terms of both CPUE and presence/absence patterns. This differentiation appeared to be driven by the 
differential effects of the degree of water loss and/or time elapsed since flow among waterhole groups, as evidenced by their differentiation in relation to the suite of water chemistry characteristics measured. Such differentiation of fish assemblages in relation to antecedent hydrology and to a lesser extent, water chemistry, has also been found in fish assemblages of the Warrego River, upper Murray-Darling Basin and in Cooper Creek, a dryland river within the Lake Eyre Basin (Arthington et al., 2005; Balcombe et al., 2006; Balcombe and Arthington, 2009).

In contrast to the assemblage patterns found in Novemeber, fish assemblage structure based on relative abundance of species in March 2003 were less distinct, with only MW waterholes differentiated from BAR and FP. Nevertheless, this differentiation was not evident from the species presence/absence data. After periods of flow, waterhole groups still remained differentiated by their water chemistry, presumably due to the differences in flow inputs to some waterholes (e.g BAR and MW sites) and drying in others (FP sites). However, there was a surprising lack of response in fish abundance in BAR sites, in that all had received significant flow pulses prior to March 2003, and yet were not differentiated from fish assemblages in FP sites. Given that only one FP site had received any incoming flow (Punbougal),

415 we would have predicted the FP group to have had depressed abundances and species richness in comparison to in-channel waterhole groups that had received significant inflows. This result may indicate the poor condition of the Macintyre and Barwon River fish populations in our study area, in that we did not detect a strong assemblage change due to increased numbers of fish and species that might have resulted from 420 flow-induced immigration and juvenile recruitment (cf. King et al., 2003; Arrington and Winemiller, 2004; Balcombe and Arthington, 2009). Poor fish assemblage response to flow in the BAR waterhole group contrasts with increased abundance and species richness in the MW sites and Punbougal Lagoon in March 2003 following flow inputs.

425 The lack of response in yellowbelly abundance in March 2003 following flow in the Barwon River may present a specific indicator of the generally depressed condition of the fish assemblages in this regulated river. At the same time, there was a strong recruitment response in both Moonie and Weir rivers. Increased abundance of yellowbelly has been shown to correspond strongly to flow pulses in the northern

430 MDB via high juvenile recruitment (Balcombe et al., 2006; Sternberg, 2008). The closely related Lake Eyre yellowbelly (Macquaria sp.) also shows a strong recruitment response to flow (Arthington et al., 2005; Balcombe and Arthington, 2009).

Initially we had expected that waterhole physical factors would be strong 435 determinants of differences in fish assemblages among the three waterhole groups. However, the morphological differences among the three waterhole groups, most notably MW and FP waterholes, were not strongly reflected in patterns of fish assemblage structure. The BIO-ENV analysis indicated that fish assemblages patterns were not associated with physical waterhole/habitat variables, with no significant 440 relationships present. However, BIO-ENV did demonstrate a link between fish assemblage structure and water chemistry, particularly turbidity in relation to species abundances in both November 2002 and March 2003.

Although differences in the physical features among waterhole groups were not concordant with patterns in fish assemblage structure, there were some significant correlations between individual species abundances and particular physical factors. Yellowbelly abundance was negatively correlated with both waterhole area and wetted perimeter on both sampling occasions, while carp numbers were also 
negatively correlated with cross-sectional area on both occasions. These relationships appear to reflect the higher abundances of yellowbelly and carp in MW waterholes rather than these species seeking out or persisting in particular waterholes based upon their size, basin shape or wetted perimeter. Similarly for water chemistry variables, the most consistent relationships were the positive correlations between bony bream and conductivity level, and turbidity and the abundance of carp.

The analytical approach we used appears to have merit, particularly its ability to categorise patterns of fish assemblage structure among waterhole groups based on hydrological history/flow disturbance. These patterns were strongest in November 2002, when all waterholes within each 'group' had experienced the most similar conditions, i.e. several months without inflow and gradual drying. This pattern largely disintegrated due to the fish assemblages in the FP waterholes following different trajectories, including two completely drying, two drying down severely, one drying to a lesser extent and one (Punbougal) actually increasing in volume. It must be noted that for both MW and BAR waterholes, the fish assemblages (based on CPUE and presence absence) remained within distinct groups on both sampling occasions. Most notably, the BAR waterholes were species and abundance poor, possibly due to the long history of flow regulation in the Macintyre - Barwon River system (> 60 years; Thoms and Sheldon, 2000) which may have depressed the potential for pulses of recruitment to occur even after flow events and improvements in water chemistry.

In summary, this study demonstrates several important features of fish assemblages in unregulated and regulated dryland rivers. Geomorphological parameters alone do not enable clear categorisation of waterhole types in dryland rivers and their floodplains in this part of the Murray-Darling Basin. We cannot expect to be able to predict fish assemblage richness and species abundances largely from basic morphological features, as shown for Cooper Creek (Arthington et al.,

475 2005). The drivers of differences in fish assemblage patterns appear more complex than simple morphological typologies can reveal, evidently being associated more strongly with the water chemistry, which may reflect differences in antecedent hydrology and connectivity.. These factors also drive spatial variations in the fish assemblages in other floodplain river systems (Rodriguez and Lewis, 1997). However in the highly variable hydrological environment of our study area, distribution patterns of individual fish species appeared to be unpredictable apart from a few instances such as the ubiquity of bony bream and the association of yellowbelly with waterholes in the MW sites.

Overall, our results strongly suggest that the largely unregulated rivers of the upper Murray-Darling Basin are in better ecological condition and able to support recruiting populations, whereas fish recruitment (e.g. yellowbelly) in the regulated rivers may have been suppressed by successive years without strong flood pulses that enable populations to remain resilient even after natural dry periods (cf Warrego R., Cooper Creek, Arthington et al., 2005; Balcombe et al., 2006).

These findings have implications for the management of hydrological regimes and the provision of environmental flows in regulated rivers of the upper MurrayDarling Basin. They extend evidence of the deleterious effects of flow regulation in rivers of the Murray-Darling Basin (Gherke et al., 1995; MDBC, 2004; King et al. 2009) and support the need for environmental water allocations to enhance fish 495 recruitment, particularly for species of fisheries significance such as the yellowbelly. As in many other floodplain rivers, the primary threat to fish diversity and population processes is reduced flood frequency, intensity and duration caused by upstream 
impoundments (Thomaz et al., 2004). Our finding that the fish assemblages of relatively undisturbed Moonie and Weir Rivers are in better ecological condition, and support recruiting populations of yellowbelly, provides a sound ecological rationale for flow restoration and other ecologically beneficial water management strategies in the more regulated Macintyre and Barwon rivers.

ACKNOWLEDGEMENTS

The authors would like to thank the various Dryland River Refugia project team members and volunteers who provided field support, and the numerous landholders for their property access and support. Our research was conducted under Queensland Fisheries Permit PRM00157K and Griffith University Animal Experimentation Ethics Committee permit AES/03/02.

\section{REFERENCES}

APHA. 1975. Standard Methods for the Examination of Water and Wastewater. $14^{\text {th }}$ edn. (American Public Health Association: Washington, DC.)

Arrington DA, Winemiller KO. 2004. Organization and maintenance of fish diversity in shallow waters of tropical floodplain rivers. In 'Proceedings of the Second International Symposium on the Management of Large Rivers for Fisheries.' (Eds R. L. Welcomme R. L. and T. Petr.) Volume II, pp. 25-36. RAP Publication 2004/17. (FAO Regional Office for Asia and the Pacific: Bangkok, Thailand.)

Arthington AH. 1996. The effects of agricultural land use on tributaries of the Darling River, Australia. GeoJournal 40: (1-2): 115-125.

Arthington A H, Balcombe SR, Wilson GG, Thoms MC, Marshall JC. 2005. Spatial and temporal variation in fish assemblage structure in isolated waterholes during the 2001 dry season of an arid-zone river, Cooper Creek, Australia. Marine and Freshwater Research 56: 25-35.

Arthington AH, Bunn SE, N. Poff NL, Naiman R J. 2006. The challenge of providing environmental flow rules to sustain river ecosystems. Ecological Applications

530 16: 1311-1318.

Balcombe SR, Arthington AH. 2009. Temporal changes in fish abundance in response to hydrological variability in a dryland floodplain river. Marine and Freshwater Research 60: 146-159.

Balcombe SR, Bunn SE, Arthington A H, Fawcett JH, McKenzie-Smith FJ, Wright A. 2007. Fish larvae, growth and biomass relationships in an Australian arid zone river: links between floodplains and waterholes. Freshwater Biology 52: 23852398.

Balcombe SR, Arthington AH, Foster ND, Thoms MC, Wilson GG, Bunn SE. 2006. Fish assemblages of an Australian dryland river: abundance, assemblage structure and recruitment patterns in the Warrego River, Murray-Darling Basin. Marine and Freshwater Research 57: 619-633.

Biggs AJW, Power RE, Silburn DM, Owens JS, Burton DWG, Hebbard CL. 2005. "Salinity Audit: Border Rivers and Moonie Catchments, Queensland MurrayDarling Basin", Department of Natural Resources and Mines, Toowoomba.

545 Bunn SE, Arthington AH. 2002. Basic principles and ecological consequences of altered flow regimes for aquatic biodiversity. Environmental Management 30: 492-507. 
Bunn SE, Davies PM, Winning M. 2003. Sources of organic carbon supporting the food web of an arid zone floodplain river. Freshwater Biology 49: 619-635.

Bunn SE, Thoms MC, Hamilton SK, Capon SJ. 2006. Flow variability in dryland rivers: boom, bust and the bits in between. River Research and Applications 22: $179-186$.

Clarke KR, Ainsworth M. 1993. A method of linking multivariate community structure to environmental variables. Marine Ecology Progress Series 92: 205555219.

Clark KR, Gorley RN. 2001. 'Primer v5: User Manual/Tutorial.' (PRIMER-E Ltd: Plymouth.)

Clarke KR, Warwick RM. 2001. Change in Marine Communities: An Approach to Statistical Analysis and Interpretation. 2nd edn. (PRIMER-E Ltd: Plymouth.)

CSIRO. 2007. Border Rivers Summary and Regional Report: Summary of a report to the Australian Government from the CSIRO Murray-Darling Basin Sustainable Yields Project. CSIRO Publishing. Available online (22/4/2008): http://www.csiro.au/resources/BorderRiversMDBSY.html

Davies BR, Thoms MC, Walker KF, O'Keefe J, Gore JA. 1994. Arid and semi-aridland river ecosystems: Perspectives on ecological functioning and problems of management and conservation. In 'Rivers Handbook, Volume 2.' (Eds. P. Calow. and G. E. Petts pp. 484-511. (Blackwell Scientific, Oxford.)

Gehrke PC, Brown P, Schiller CB, Moffatt DB, Bruce AM. 1995. River regulation and fish communities in the Murray-Darling River system, Australia.

$570 \quad$ Regulated Rivers: Research and Management 10: 15-38.

Junk WJ, Bayley PB, Sparks RE. 1989. The Flood Pulse Concept in river-floodplain Systems. Proceedings of the International Large Rivers Symposium (LARS) (Ed. D. P. Dodge.). Canadian Journal of Fisheries and Aquatic Sciences Special Publication 106: 110-27.

575 Keppel G. 1991. 'Design and Analysis: a Researcher’s Handbook'. (Prentice-Hall: New Jersey, USA.)

King, AJ, Humphries P, Lake PS. 2003. Fish recruitment on floodplains; the roles of patterns of flooding and life history characteristics. Canadian Journal of Fisheries and Aquatic Sciences 60: 773-786.

580 King AJ, Ward KA, O’Connor P, Tonkin Z, Mahoney J. 2009. Adaptive management of an environmental watering event to enhance native fish spawning and recruitment Freshwater Biology DOI: 10.1111/j.1365-2427.2009.02178.x

Kingsford RT. 2006. Changing desert rivers. In 'Ecology of Desert Rivers'. (Ed. R.T. Kingsford.) pp. 336-345. (Cambridge University Press, Melbourne.)

MDBC. 2004. Native Fish Strategy for the Murray-Darling Basin 2003-2013.

Murray-Darling Basin Commission, Canberra. www.mdbc.gov.au

Parsons ME, Thoms M.C, Norris RN. 2004. Development of a standardised approach to river habitat assessment in Australia. Environmental Monitoring and Assessment 98: 109-130.

590 Poff NL, Richter BD, Arthington AH, Bunn SE, Naiman RJ, Kendy E, Acreman M, Apse C, Bledsoe BP, Freeman MC, Henriksen J, Jacobson RB, Kennen, JG, Merritt DM, O’Keeffe JH, Olden JD, Rogers K, Tharme RE, Warne A. 2009. The ecological limits of hydrologic alteration (ELOHA): a new framework for developing regional environmental flow standards, Freshwater Biology (DOI 2009). 
Puckridge JT, Walker KF, Costelloe, JF. 2000. Hydrological persistence and the ecology of dryland rivers. Regulated Rivers: Research and Management 16: 385-402.

Pusey BJ, Kennard M.J, Arthington AH. 2004. Freshwater Fishes of North-eastern Australia, 684 pp. (CSIRO Publishing: Collingwood, Australia.)

Rodriguez MA, Lewis WM.Jr. 1997. Structure of fish assemblages along environmental gradients in floodplain lakes of the Orinoco River. Ecological Monographs 67: 109-28.

Sternberg D. 2008. Investigating the influence of deterministic mechanisms on the distribution and abundance of fish in dryland rivers using Macquaria ambigua (Percichthidae) as an indicator species. Unpublished Honours Thesis, Griffith University, Nathan Campus, Qld.

Systat Software, Inc. (SSI), (2004). 'Systat ${ }^{\circledR}$ for Windows ${ }^{\circledR}$.' (Richmond: CA).

Thoms MC, Sheldon F. 2000. Water resource development and hydrological change in a large dryland river: the Barwon-Darling River, Australia. Journal of Hydrology 228: 10-21.

Thoms MC, Southwell M, McGinness HM. 2005. Floodplain-river ecosystems: Fragmentation and water resources development. Geomorphology 71: 126138.

615 Thomaz SM, Agostinho AA, Hahn NS. editors. 2004. The Upper Paran'a River and its floodplain: physical aspects, ecology and conservation. Backhuys Publishers, Leiden, The Netherlands.

Walker KF, Thoms MC. 1993. Environmental effects of flow regulation on a semiarid lowland river: the River Murray, South Australia. Regulated Rivers: Research and Management 7: 103-119.

Welcomme RL, Bene C, Brown CA, Arthington AH, Dugan P, King JM, Vasu Sugunan V. 2006. Predicting the water requirements of river fisheries. In: Wetlands and Natural Resource Management (J.T.A. Verhoeven, B. Beltman, R. Bobbink and D.F. Whigham, Eds). Ecological Studies Vol. 190, SpringerVerlag, Berlin, Heidelberg, p. 123-154. 
Table I. Waterhole geomorphology and habitat variables (and abbreviations) measured at three spatial scales in the Macintyre, Barwon and Border Rives catchments.

\begin{tabular}{lll}
\hline Landscape & Entire waterhole & Within waterhole \\
\hline Total floodplain width (TFW) & Area (A) & Hydraulic radius (HR) \\
Effective floodplain width (EFW) & Width to depth ratio (WD) & Depth of cross section (DCS) \\
Bifurcation ratio (BR) & Wetted perimeter (WP) & Area of cross section (ACS) \\
& Shape index (SI) & Mid-channel bars (MCB) \\
& Fetch length (FL) & Backwater (BAW) \\
& Perimeter (P) & Off-take channels (OC) \\
& Length (L) & Bench 0 - 1/3 (B1) \\
Circularity (C) & Bench 1/3 - 2/3 (B2) \\
& Elongation ratio (ER) & Bench 2/3-3/3 (B3) \\
& Length to width ratio (LW) & Side bars (SB) \\
& Volume (V) & Backwater (BAW) \\
& Anabranches (AN) \\
& Bed and bank complexity (BBC) \\
& Eroding banks (EB) \\
& Snags (SN) \\
& & Anabranches (AN) \\
& Boulders (BOU) \\
& Fringing vegetation (FV) \\
& Overhanging vegetation (OV)
\end{tabular}


Table II. Variation in waterhole geomorphology and water chemistry parameters between the three waterhole groups. Data are reported as medians and ranges.

\begin{tabular}{|c|c|c|c|c|c|c|}
\hline \multirow[b]{2}{*}{ Basic Geomorphology } & \multicolumn{2}{|c|}{ BAR } & \multicolumn{2}{|c|}{ FP } & \multicolumn{2}{|c|}{ MW } \\
\hline & & & & & & \\
\hline Total Floodplain width (km) & 15.9 & $9.79-56.1$ & 59.0 & $6.71-640$ & 48.0 & $1.98-61.3$ \\
\hline Area $\left(\mathrm{m}^{2} \times 10^{3}\right)$ & 58.8 & $47.3-173$ & 158 & 19.6-511 & 10.7 & 8.38-17.2 \\
\hline$V\left(m^{3} \times 10^{3}\right)$ & 448 & $336-2250$ & 779 & $123-2900$ & 59.9 & $43.4-1130$ \\
\hline $\mathrm{P}(\mathrm{m})$ & 2734 & $\begin{array}{r}2369- \\
7511\end{array}$ & 5605 & $\begin{array}{r}1314- \\
8460\end{array}$ & 1091 & $\begin{array}{r}728- \\
10110\end{array}$ \\
\hline $\mathrm{L}$ & 1320 & $\begin{array}{r}1079- \\
3607\end{array}$ & 2500 & $614-4133$ & 503 & $341-5039$ \\
\hline \multicolumn{7}{|l|}{$\begin{array}{l}\text { November } 2002 \text { water } \\
\text { chemistry }\end{array}$} \\
\hline Conductivity@25ㄷ $\left(\mu \mathrm{Scm}^{-1}\right)$ & 360 & $275-385$ & 473 & $325-990$ & 200 & $150-260$ \\
\hline $\mathrm{pH}$ & 7.7 & $7.55-7.75$ & 7.75 & $7.5-5.25$ & 7.2 & $7.15-7.25$ \\
\hline Turbidity (NTU) & 83 & 8-105 & 285 & $28-2000$ & 1475 & $\begin{array}{r}1000- \\
2000\end{array}$ \\
\hline Alkalinity as $\mathrm{CaCO}_{3}\left(\mathrm{mg} \mathrm{L}^{-1}\right)$ & 130 & $105-145$ & 200 & $110-330$ & 68 & $56-81$ \\
\hline Silica $\left(\mathrm{mg} \mathrm{L}^{-1}\right)$ & 6 & 3-10 & 17 & 4-29 & 27 & 19-33 \\
\hline Total suspended solids $\left(\mathrm{mg} \mathrm{L}^{-1}\right)$ & 60 & $30-90$ & 220 & $5-1000$ & 635 & $250-1700$ \\
\hline Total Nitrogen as $\mathrm{N}\left(\mathrm{mg} \mathrm{L}^{-1}\right)$ & 0.8 & $0.4-0.9$ & 1.7 & $1.1-4.2$ & 2.7 & 1.7 \\
\hline $\begin{array}{l}\text { 3.6Total Phosphorus as P (mg } \\
\mathrm{L}^{-1} \text { ) }\end{array}$ & 0.08 & $0.06-0.09$ & 0.42 & $0.09-1.0$ & 0.9 & $0.57-1.5$ \\
\hline Sodium (mg L $\left.{ }^{-1}\right)$ & 31 & $18-34$ & 54 & 39-135 & 22 & $18-27$ \\
\hline Potassium $\left(\mathrm{mg} \mathrm{L}^{-1}\right)$ & 4.0 & 2.9-4.3 & 12 & 8.4-16 & 7.1 & $6.1-8.2$ \\
\hline Calcium (mg L $\left.{ }^{-1}\right)$ & 22 & $16-24$ & 25 & $14-42$ & 8.1 & $5.9-12$ \\
\hline Magnesium (mg L $\left.{ }^{-1}\right)$ & 14 & $12-15$ & 12 & 7.1-32 & 3.7 & $2.4-7.1$ \\
\hline Bicarbonate (mg L ${ }^{-1}$ ) & 160 & $130-175$ & 243 & $130-390$ & 83 & $69-98$ \\
\hline Carbonate (mg L ${ }^{-1}$ ) & 0.5 & $0.3-0.5$ & 0.9 & $0.2-4.5$ & 0.1 & $0.1-0.1$ \\
\hline Chloride $\left(\mathrm{mg} \mathrm{L}^{-1}\right)$ & 25 & 16-29 & 30 & 24-150 & 14 & $7.9-20$ \\
\hline Flouride $\left(\mathrm{mg} \mathrm{L}^{-1}\right)$ & 0.2 & $0.1-0.2$ & 0.4 & $0.3-1.0$ & 0.15 & $0.1-0.2$ \\
\hline Nitrate $\left(\mathrm{mg} \mathrm{L}^{-1}\right)$ & 1.0 & $0.5-2.0$ & 2.0 & $1.2-6.7$ & 3.1 & $1.7-9.1$ \\
\hline Sulfate $\left(\mathrm{mg} \mathrm{L}^{-1}\right)$ & 13 & $2.2-15$ & 12 & 6.4-65 & 5.7 & $4.9-12$ \\
\hline \multicolumn{7}{|l|}{ March 2003 water chemistry } \\
\hline Conductivity@25ㄷ $\left(\mu \mathrm{Scm}^{-1}\right)$ & 230 & $220-290$ & 273 & $115-1300$ & 493 & $150-790$ \\
\hline $\mathrm{pH}$ & 7.5 & 7.5-8.2 & 7.8 & 7.3-8.8 & 7.7 & 7.2-8.4 \\
\hline Turbidity (NTU) & 245 & $47-360$ & 738 & $14-1450$ & 298 & $76-960$ \\
\hline Alkalinity as $\mathrm{CaCO}_{3}\left(\mathrm{mg} \mathrm{L}^{-1}\right)$ & 75 & $70-115$ & 101 & $46-440$ & 189 & $54-365$ \\
\hline Silica $\left(\mathrm{mg} \mathrm{L}^{-1}\right)$ & 16 & $15-18$ & 13 & 3-18 & 21 & $14-22$ \\
\hline Total suspended solids $\left(\mathrm{mg} \mathrm{L}^{-1}\right)$ & 150 & $40-330$ & 165 & $20-270$ & 190 & $80-290$ \\
\hline Total Nitrogen as $\mathrm{N}\left(\mathrm{mg} \mathrm{L}^{-1}\right)$ & 1.3 & 0.6-1.4 & 2.3 & 1.2-2.6 & 1.9 & 1.6-2.8 \\
\hline Total Phosphorus as $\mathrm{P}\left(\mathrm{mg} \mathrm{L}^{-1}\right)$ & 0.26 & $0.15-0.31$ & 0.70 & $0.44-0.83$ & 0.67 & $0.38-0.78$ \\
\hline Sodium $\left(\mathrm{mg} \mathrm{L}^{-1}\right)$ & 19 & $18-22$ & 34 & $15-230$ & 52 & $18-120$ \\
\hline Potassium $\left(\mathrm{mg} \mathrm{L}^{-1}\right)$ & 3.7 & $3.2-4.0$ & 8.6 & 5-22 & 11.7 & $4.4-19$ \\
\hline Calcium (mg L $\left.{ }^{-1}\right)$ & 14 & 13-18 & 12 & $4.7-28$ & 28 & $5.9-42$ \\
\hline Magnesium (mg L ${ }^{-1}$ ) & 8.6 & 8.3-13.5 & 7.4 & $2.2-30$ & 13 & 3-23 \\
\hline Bicarbonate $\left(\mathrm{mg} \mathrm{L}^{-1}\right)$ & 91 & 86-135 & 124 & $55-495$ & 228 & $66-430$ \\
\hline Carbonate (mg L ${ }^{-1}$ ) & 0.2 & $0.1-1.3$ & 0.7 & 0.1-20 & 1.0 & $0.1-7.3$ \\
\hline Chloride $\left(\mathrm{mg} \mathrm{L}^{-1}\right)$ & 18 & $16-21$ & 19 & $5.9-125$ & 32 & 9.4-61 \\
\hline Flouride $\left(\mathrm{mg} \mathrm{L}^{-1}\right)$ & 0.2 & $0.2-0.2$ & 0.35 & $0.1-0.6$ & 0.5 & $0.2-0.7$ \\
\hline Nitrate $\left(\mathrm{mg} \mathrm{L}^{-1}\right)$ & 2.3 & $0.6-2.5$ & 2.2 & $2.1-3.0$ & 2.9 & $2.3-5.4$ \\
\hline Sulfate $\left(\mathrm{mg} \mathrm{L}^{-1}\right)$ & 11 & 8.4-12 & 6.9 & 2.7-99 & 11 & $5.2-15$ \\
\hline
\end{tabular}


640 Table III. Summary of ANOSIM results comparing the three waterhole groups based on geomorphology and water quality. Note: Waterhole group: BAR = Macintyre and Barwon rivers, $\mathrm{FP}=$ floodplain, $\mathrm{MW}=$ Moonie/Weir rivers

\begin{tabular}{|c|c|c|c|}
\hline Factor & $\begin{array}{l}\text { Global } \\
\text { R }\end{array}$ & $\mathbf{P}$ & Significant pairwise tests \\
\hline Large scale geomorphology & 0.197 & 0.04 & MW-FP (0.04) \\
\hline $\begin{array}{l}\text { Waterhole scale } \\
\text { geomorphology }\end{array}$ & 0.379 & 0.001 & BAR-FP (0.002), MW-FP (0.005) \\
\hline $\begin{array}{l}\text { Water chemistry-November } \\
2002\end{array}$ & 0.61 & 0.001 & $\begin{array}{l}\text { BAR-FP (0.004), BAR-MW (0.008), MW-FP } \\
(0.01)\end{array}$ \\
\hline Water chemistry-March 2003 & 0.709 & 0.001 & $\begin{array}{l}\text { BAR-FP (0.008), BAR-MW (0.008), MW-FP } \\
(0.03)\end{array}$ \\
\hline
\end{tabular}

645 
Table IV. Fish species (and code) caught in waterholes in the four study rivers and nearby floodplains, November 2002 and March 2003.

\begin{tabular}{|c|c|c|}
\hline Family/species & Common name & Species code \\
\hline \multicolumn{3}{|l|}{ Indigenous species } \\
\hline \multicolumn{3}{|l|}{ Ambassidae } \\
\hline Ambassis agasizzii Steindachner, 1867 & olive perchlet & AMB \\
\hline \multicolumn{3}{|l|}{ Clupeidae } \\
\hline Nematolosa erebi (Günther, 1868) & & NEM \\
\hline \multicolumn{3}{|l|}{ Atherinidae } \\
\hline Craterocephalus stercusmuscarum fulvus & $\begin{array}{l}\text { fly-specked } \\
\text { hardyhead }\end{array}$ & CRA \\
\hline \multicolumn{3}{|l|}{ Gobiidae } \\
\hline $\begin{array}{l}\text { Hypseleotris spp. } \\
\text { Melanotaeniidae }\end{array}$ & carp gudgeons & HYP \\
\hline $\begin{array}{l}\text { Melanotaenia fluviatilis (Castelnau, } \\
\text { 1878) }\end{array}$ & $\begin{array}{l}\text { crimson-spotted } \\
\text { rainbowfish }\end{array}$ & MEL \\
\hline \multicolumn{3}{|l|}{ Percichthyidae } \\
\hline Maccullochella peeli peeli & Murray cod & MPP \\
\hline Macquaria ambigua (Richardson, 1845) & golden perch & MAC \\
\hline \multicolumn{3}{|l|}{ Plotosidae } \\
\hline \multicolumn{3}{|l|}{ Retropinnidae } \\
\hline $\begin{array}{l}\text { Leiopotherapon unicolor (Günther, } \\
\text { 1859) }\end{array}$ & spangled perch & LEI \\
\hline \multicolumn{3}{|l|}{ Alien species } \\
\hline \multicolumn{3}{|l|}{ Cyprinidae } \\
\hline Carassius auratus (Linnaeus, 1758) & goldfish & CAR \\
\hline Cyprinus carpio (Linnaeus, 1758) & common carp & CYP \\
\hline Poeciliidae & & \\
\hline Gambusia holbrooki (Girard, 1859) & mosquitofish & GAM \\
\hline
\end{tabular}


Table V. Fish catch per unit effort (CPUE) for individual species in the 15 study waterholes, November 2002 (Time 1) and March 2003 (Time 2). Species codes are given in Table IV.

\begin{tabular}{|c|c|c|c|c|c|c|c|c|c|c|c|c|c|c|c|c|c|c|}
\hline Waterhole & Reach & Group & Time & AMB & CRAT. & NEM & MEL & HYP & MPP & MAC & TAN & RET & LEI & CAR & CYP & GAM & $\begin{array}{r}\text { TOTAL } \\
\text { CPUE }\end{array}$ & RICHNESS \\
\hline Ironbark Wh. & G & BAR & 1 & 8 & 0 & 0 & 9 & 1 & 1 & 1 & 0 & 0 & 0 & 0 & 0 & 0 & 20 & \\
\hline Ironbark Wh. & G & BAR & 2 & 4 & 1 & 8 & 2 & 1 & 0 & 5 & 0 & 1 & 0 & 0 & 0 & 0 & 22 & \\
\hline Whalan Ck. & G & FP & 1 & 0 & 0 & 50 & 0 & 5 & 0 & 0 & 0 & 0 & 6 & 3 & 2 & 0 & 66 & \\
\hline Whalan Ck. & G & FP & 2 & - & - & - & - & - & - & - & - & - & - & - & - & - & - & \\
\hline Maynes Lg. & G & $\mathrm{FP}$ & 1 & 0 & 0 & 76 & 0 & 0 & 0 & 0 & 0 & 0 & 0 & 0 & 0 & 0 & 76 & \\
\hline Maynes Lg. & G & FP & 2 & 0 & 0 & 130 & 0 & 0 & 0 & 0 & 0 & 10 & 0 & 1 & 1 & 0 & 142 & \\
\hline Punbougal Lg. & G & $\mathrm{FP}$ & 1 & 0 & 0 & 109 & 2 & 34 & 0 & 0 & 0 & 0 & 10 & 0 & 0 & 0 & 155 & \\
\hline Punbougal Lg. & G & $\mathrm{FP}$ & 2 & 0 & 0 & 306 & 10 & 136 & 0 & 0 & 0 & 0 & 1 & 2 & 0 & 0 & 455 & \\
\hline Wolonga Lg. & $\mathrm{T}$ & FP & 1 & 0 & 0 & 35 & 0 & 1 & 0 & 8 & 0 & 0 & 3 & 2 & 14 & 0 & 63 & \\
\hline Wolonga Lg. & $\mathrm{T}$ & FP & 2 & - & - & - & - & - & - & - & - & - & - & - & - & - & - & \\
\hline Newinga Wh. & $\mathrm{T}$ & MW & 1 & 0 & 0 & 0 & 0 & 0 & 0 & 3 & 0 & 0 & 0 & 6 & 6 & 0 & 15 & \\
\hline Newinga Wh. & $\mathrm{T}$ & MW & 2 & 0 & 0 & 15 & 0 & 0 & 0 & 9 & 0 & 0 & 0 & 5 & 2 & 4 & 35 & \\
\hline Mill Wh. & $\mathrm{T}$ & MW & 1 & 0 & 0 & 0 & 0 & 0 & 0 & 3 & 0 & 0 & 0 & 0 & 3 & 0 & 6 & \\
\hline Mill Wh. & $\mathrm{T}$ & MW & 2 & 0 & 0 & 28 & 1 & 11 & 0 & 96 & 2 & 0 & 2 & 2 & 4 & 0 & 146 & \\
\hline Kanowna Wh. & $\mathrm{T}$ & BAR & 1 & 0 & 0 & 10 & 8 & 0 & 0 & 2 & 0 & 2 & 0 & 0 & 0 & 0 & 22 & \\
\hline Kanowna Wh. & $\mathrm{T}$ & BAR & 2 & 0 & 0 & 100 & 0 & 0 & 0 & 2 & 0 & 0 & 0 & 3 & 0 & 0 & 105 & \\
\hline Goondoobluie Wh. & M & MW & 1 & 0 & 0 & 0 & 0 & 0 & 0 & 0 & 1 & 0 & 0 & 6 & 8 & 0 & 15 & \\
\hline Goondoobluie Wh. & M & MW & 2 & 0 & 0 & 10 & 0 & 0 & 0 & 25 & 1 & 0 & 1 & 1 & 8 & 0 & 46 & \\
\hline Tchuringa Wh. & M & MW & 1 & 0 & 0 & 0 & 0 & 0 & 0 & 9 & 0 & 0 & 0 & 0 & 19 & 0 & 28 & \\
\hline Tchuringa Wh. & M & MW & 2 & 0 & 0 & 1 & 0 & 0 & 0 & 32 & 0 & 0 & 1 & 2 & 6 & 1 & 43 & \\
\hline Rocky Wh. & M & BAR & 1 & 0 & 0 & 10 & 6 & 1 & 0 & 1 & 2 & 0 & 0 & 0 & 1 & 0 & 21 & \\
\hline Rocky Wh. & M & BAR & 2 & 0 & 0 & 28 & 1 & 0 & 1 & 3 & 0 & 0 & 0 & 0 & 4 & 0 & 37 & \\
\hline Saltbush Wh. & M & BAR & 1 & 0 & 0 & 15 & 4 & 2 & 0 & 4 & 0 & 0 & 0 & 0 & 5 & 0 & 30 & \\
\hline Saltbush Wh. & M & BAR & 2 & 0 & 0 & 41 & 0 & 0 & 0 & 5 & 0 & 0 & 0 & 0 & 6 & 0 & 52 & \\
\hline Wirrabilla Lg. & $\mathrm{C}$ & FP & 1 & 0 & 0 & 172 & 1 & 12 & 0 & 2 & 0 & 1 & 0 & 0 & 2 & 0 & 190 & \\
\hline Wirrabilla Lg. & $\mathrm{C}$ & FP & 2 & 0 & 0 & 153 & 0 & 0 & 0 & 0 & 0 & 0 & 0 & 0 & 1 & 0 & 154 & \\
\hline Gnungarah Ck. & $\mathrm{C}$ & FP & 1 & 0 & 0 & 19 & 0 & 5 & 0 & 2 & 0 & 0 & 1 & 1 & 8 & 0 & 36 & \\
\hline Gnungarah Ck. & $\mathrm{C}$ & FP & 2 & 0 & 0 & 49 & 0 & 0 & 0 & 3 & 0 & 0 & 0 & 0 & 0 & 0 & 52 & \\
\hline Devil's Wh. & $\mathrm{C}$ & BAR & 1 & 0 & 0 & 15 & 3 & 0 & 0 & 1 & 0 & 0 & 0 & 5 & 0 & 0 & 24 & \\
\hline Devil's Wh. & $\mathrm{C}$ & BAR & 2 & 0 & 0 & 75 & 0 & 1 & 0 & 17 & 0 & 1 & 0 & 1 & 0 & 0 & 95 & \\
\hline total CPUE & & & & 12 & 1 & 1455 & 47 & 210 & 2 & 233 & 6 & 15 & 25 & 40 & 100 & 5 & 2151 & \\
\hline
\end{tabular}


Table VI.. Significant taxa contributing to the similarity patterns in three waterhole groups from SIMPER analysis. Species codes are given in Table IV.

\begin{tabular}{|c|c|c|c|}
\hline $\begin{array}{l}\text { Sampling } \\
\text { Time }\end{array}$ & transformation & $\begin{array}{l}\text { Waterhole } \\
\text { group }\end{array}$ & Significant taxa \\
\hline 1 & $\log _{10}$ CPUE & BAR & AS = 52; Nem (52), Mel (38), Mac (9) \\
\hline 1 & $\log _{10}$ CPUE & FP & AS = 50; Nem (87), Hyp (5) \\
\hline 1 & $\log _{10}$ CPUE & MW & AS = 47; Cyp (64), Mac (22), Car (14) \\
\hline 1 & Presence/absence & BAR & AS $=61 ;$ Mel (36), Mac (36), Nem (22) \\
\hline 1 & Presence/absence & FP & AS = 58; Nem (40), Hyp (21), Lei (13), Cyp (12), Car (6) \\
\hline 1 & Presence/absence & MW & AS = 68; Cyp (60), Mac (32) \\
\hline 2 & $\log _{10}$ CPUE & BAR & AS = 48; Nem (84), Mac (13) \\
\hline 2 & $\log _{10}$ CPUE & FP & AS $=50 ;$ Nem $(99)$ \\
\hline 2 & $\log _{10}$ CPUE & MW & AS = 48; Mac (60), Nem (20), Сур (12) \\
\hline 2 & Presence/absence & BAR & AS = 55; Nem (43), Mac (43), Cyp (5) \\
\hline 2 & Presence/absence & FP & AS $=40 ;$ Nem (78), Cyp (14) \\
\hline 2 & Presence/absence & MW & AS = 78; Nem (21), Cyp (21), Car (21), Mac (21), Lei (10) \\
\hline
\end{tabular}


Table VII. Summary of ANOSIM results comparing waterhole fish assemblages based upon CPUE and presence/absence among waterhole groups. For significant pairwise comparisons, the taxa contributing to the differences are given from SIMPER analysis. Species codes are given in Table IV. Note: Waterhole group: BAR = Macintyre and Barwon rivers, FP = floodplain, MW = Moonie/Weir Rivers.

\begin{tabular}{|c|c|c|c|c|c|}
\hline $\begin{array}{l}\text { Sampling } \\
\text { time }\end{array}$ & Transformation & Factor & $\begin{array}{l}\text { Global } \\
\text { R }\end{array}$ & $\mathbf{P}$ & Significant pairwise tests and significant taxa (\%) \\
\hline 1 & Log (CPUE +1) & Group & 0.764 & 0.001 & $\begin{array}{l}\text { BAR-FP (p = 0.002) AD=75\%, Nem (64), Hyp (8), } \\
\text { Mel (8), Cyp (7); } \\
\text { BAR-MW (p = 0.008) AD=86\%, Nem (30), Cyp } \\
\text { (22), Mel (19), Car (9), Mac (8), Amb (5); } \\
\text { FP-MW (p =0.005) AD = 88\%, Nem (71), Cyp (8), } \\
\text { Hyp (8) }\end{array}$ \\
\hline 1 & Pres/abs & Group & 0.503 & 0.001 & $\begin{array}{l}\text { BAR-FP (p = 0.03), AD= 51\%, Mel (16), Lei (13), } \\
\text { Mac (13), Hyp (12), Cyp (11), Car (10), Ret (7); } \\
\text { BAR-MW (p = 0.008), AD=63\%, Mel (23), Nem } \\
\text { (18), Cyp (14),Car (11), Hyp (9), Tan (8) Mac (5), } \\
\text { Ret (5); } \\
\text { FP-MW (p = 0.005) AD=69\%, Nem (23), Hyp (16), } \\
\text { Mac (13), Lei (13), Car (11), Cyp (11), Mel (7) }\end{array}$ \\
\hline 2 & $\log (\mathrm{CPUE}+1)$ & Group & 0.437 & 0.002 & $\begin{array}{l}\text { BAR-MW }(\mathrm{p}=0.008), \mathrm{AD}=68 \% \mathrm{Nem}(45), \text { Mac } \\
(36), \text { Cyp }(5) ; \\
\text { FP-MW }(\mathrm{p}=0.03), \mathrm{AD}=68 \% \operatorname{Nem}(64), \text { Mac }(20) \text {, } \\
\text { Hyp (9) }\end{array}$ \\
\hline 2 & Pres/abs & Reach & 0.148 & n.s. & \\
\hline
\end{tabular}


Table VIII. Summary of BIO-ENV results based on Spearman rank correlations $\left(\mathrm{r}_{\mathrm{s}}\right)$ between fish assemblage structure (CPUE and presence/absence) and water chemistry variables. Note: Results are only presented for the best possible solution.

\begin{tabular}{|c|c|c|c|c|}
\hline $\begin{array}{l}\text { Sampling } \\
\text { time }\end{array}$ & $\begin{array}{l}\text { Transformat } \\
\text { ion }\end{array}$ & 1 variable & 2 variables & 3 variables \\
\hline \multicolumn{5}{|l|}{ Water } \\
\hline Chemistry & & & & \\
\hline 1 & $\begin{array}{l}\text { Log } \\
(\text { CPUE +1) }\end{array}$ & $\begin{array}{r}\text { Tur } \\
(0.52)\end{array}$ & Con, Tur (0.58) & Con, Tur, $\mathrm{SO}_{4}(0.61)$ \\
\hline 1 & Pres/abs & $\mathrm{pH}(0.53)$ & $\mathrm{Mg}, \mathrm{SO}_{4}(0.59)$ & $\mathrm{TC}, \mathrm{NO}_{3}, \mathrm{SO}_{4}(0.63)$ \\
\hline 2 & $\begin{array}{l}\text { Log } \\
(\mathrm{CPUE}+1)\end{array}$ & $\begin{array}{r}\text { Tur } \\
(0.69)\end{array}$ & Tur, TN (0.71) & Tur, TN, Fl (0.72) \\
\hline 2 & Pres/abs & $\begin{array}{r}\text { TSS } \\
(0.31)\end{array}$ & TSS, TN (0.35) & TSS, TN, Fl (0.35) \\
\hline
\end{tabular}


Table IX. Significant Spearman rank correlations $\left(\mathrm{r}_{\mathrm{s}}\right)$ between fish species abundance/diversity with geomorphological (codes given in Table 1) and water chemistry variables (Tur = turbidity, $\mathrm{ConToH}=$ total hardness, Sil $=$ silicates, $\mathrm{TC}=$ total carbon, TSS $=$ total suspended solids, $\mathrm{N}: \mathrm{P}=$ nitrogen:phosphorus ratio). ${ }^{*} \mathrm{p} \leq 0.005 * * \mathrm{p} \leq 0.001$

\begin{tabular}{lll}
\hline $\begin{array}{l}\text { Sampling } \\
\text { time } \\
\text { Geomorphology }\end{array}$ & Factor & Fish species, $\mathbf{r}_{\mathbf{s}} \mathbf{( p )}$ \\
1 & A & Mac $-0.81^{* *}$, Cyp $-0.65^{*}$ \\
1 & ACS & Cyp $-0.68^{*}$, Mac $-0.66^{* *}$ \\
1 & DCS & Mel $0.7^{*}$ \\
1 & WP & Mac $-0.65^{*}$ \\
1 & SI & Nem $-0.7^{*}$ Tot $-0.77^{* *}$ \\
2 & A & Nem $0.71^{*}$, Mac $-0.71^{* *}$ \\
2 & ACS & Cyp $-0.76^{*}$ \\
2 & WCS & Mac $-0.79^{* *}$ \\
2 & WD & Mac $-0.8^{* *}$ \\
2 & WP & Mac $-0.78^{*}$ \\
Water chemistry & \\
1 & Con & Nem $0.86^{* *}$, Tot $0.8^{* *}$ \\
1 & pH & Nem $0.68^{*}$ \\
1 & Tur & Cyp $0.72^{*}$, Mel $-0.81^{* *}$ \\
1 & Alk & Nem $0.83^{* *}$, Tot $0.75^{* *}$ \\
1 & NO & Mel $-0.71^{*}$ \\
2 & Con & Nem $0.82^{* *}$, Tot $0.79^{* *}$ \\
2 & Tur & Nem $-0.71^{*}$, Cyp $0.82^{* *}$, Mac $0.79^{* *}$ \\
2 & TSS & Cyp $0.78^{* *}$ \\
2 & Fl & Nem $0.79^{* *}$, Mac $-0.79^{* *}$ \\
\hline
\end{tabular}




\section{Figure Captions}

Figure 1 Simplified map of study site locations along the Macintyre, Barwon, Weir and Moonie River systems, upper Murray-Darling Basin. Note: Only rivers containing sites are shown for clarity.

Figure 2 Daily discharge data at six sites in proximity to study sites.

Figure 3. MDS plot of waterhole water chemistry based upon distance measures for a) November 2002 and b) March 2003.

Figure 4. MDS plot of waterhole geomorphology based upon distance measures for a) large scale morphology and b) within waterhole morphology.

Figure 3. MDS plot of waterhole geomorphology based upon distance measures for a) large scale morphology and b) within waterhole morphology.

Figure 4 Mean fish catch per unit effort (a. and b.) and mean species richness (c. and d.) grouped by waterhole group within the Barwon River catchment on two sampling occasions.

Figure 5 MDS plot of fish assemblage data for November 2002 and March 2003 combined based upon (a.) $\log _{10}$ transformed catch per unit effort and (b.) fish species presence/absence 


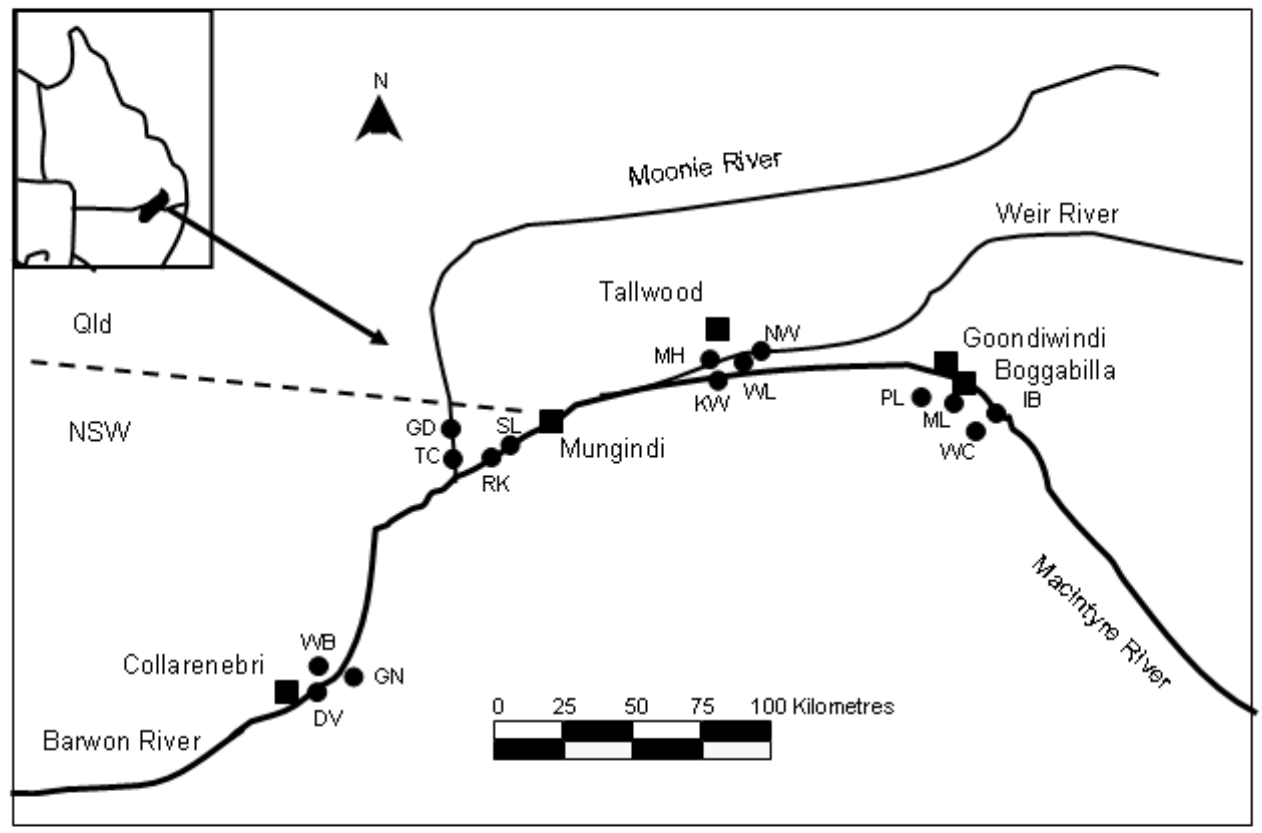

Figure 1 


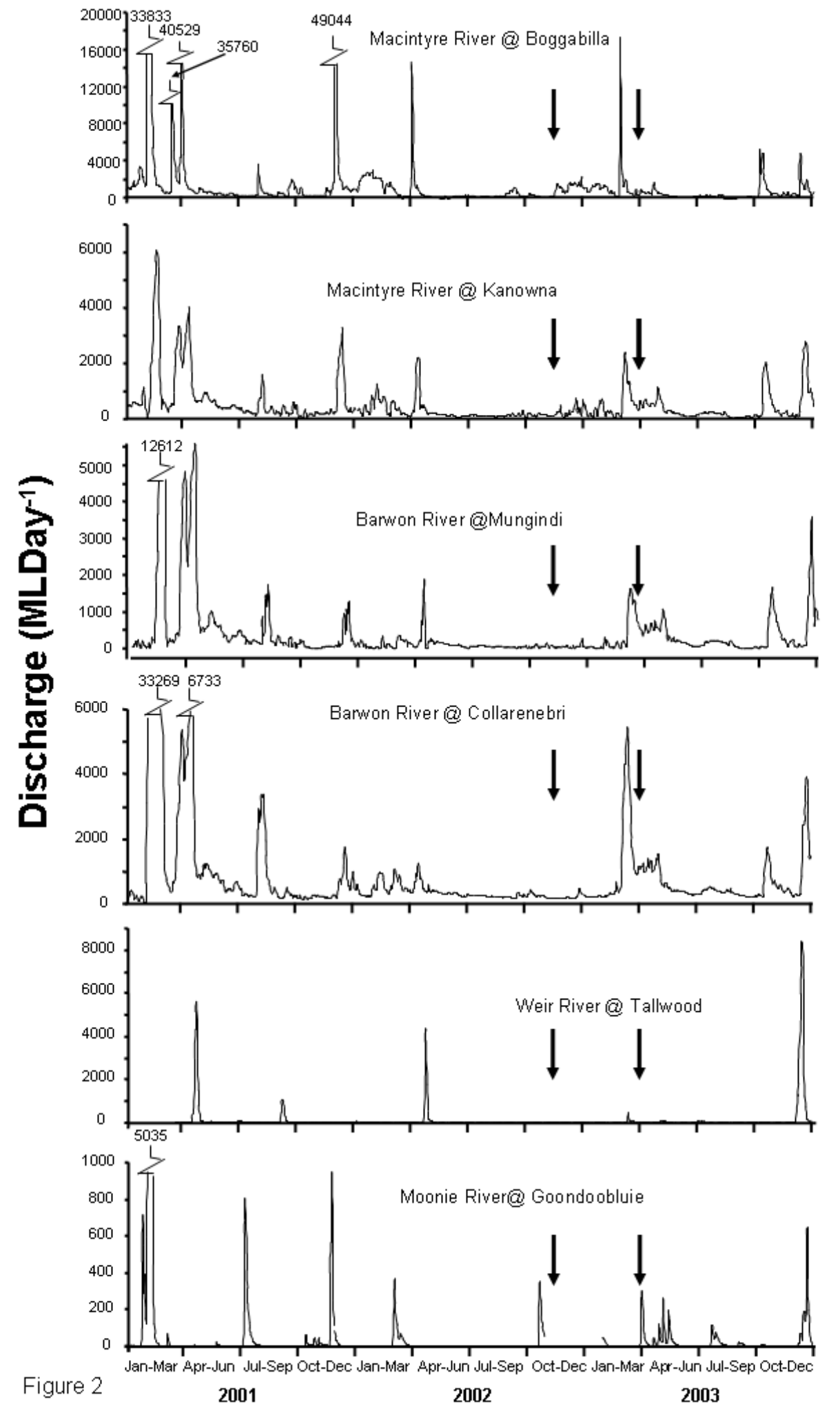



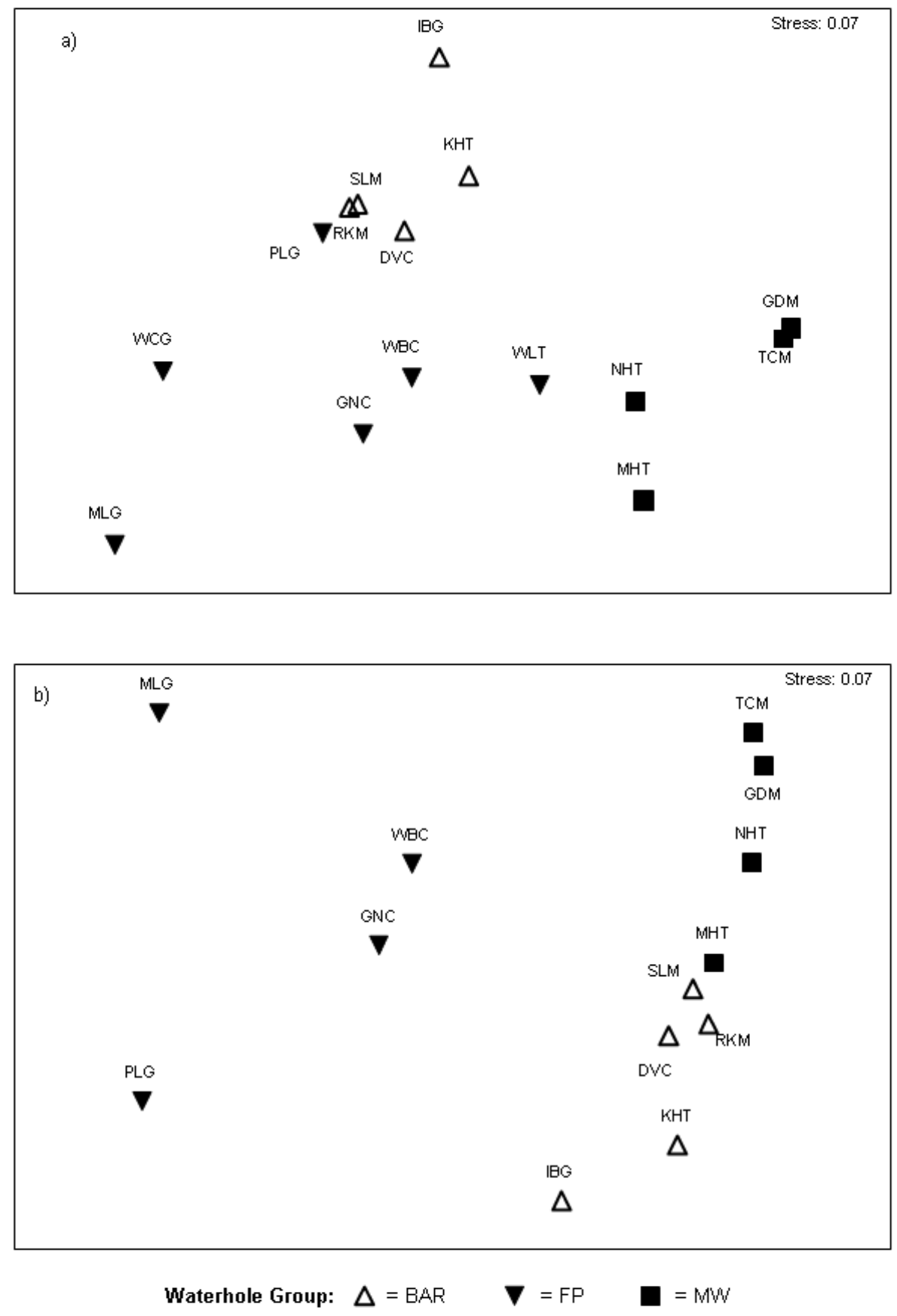

Figure 3 

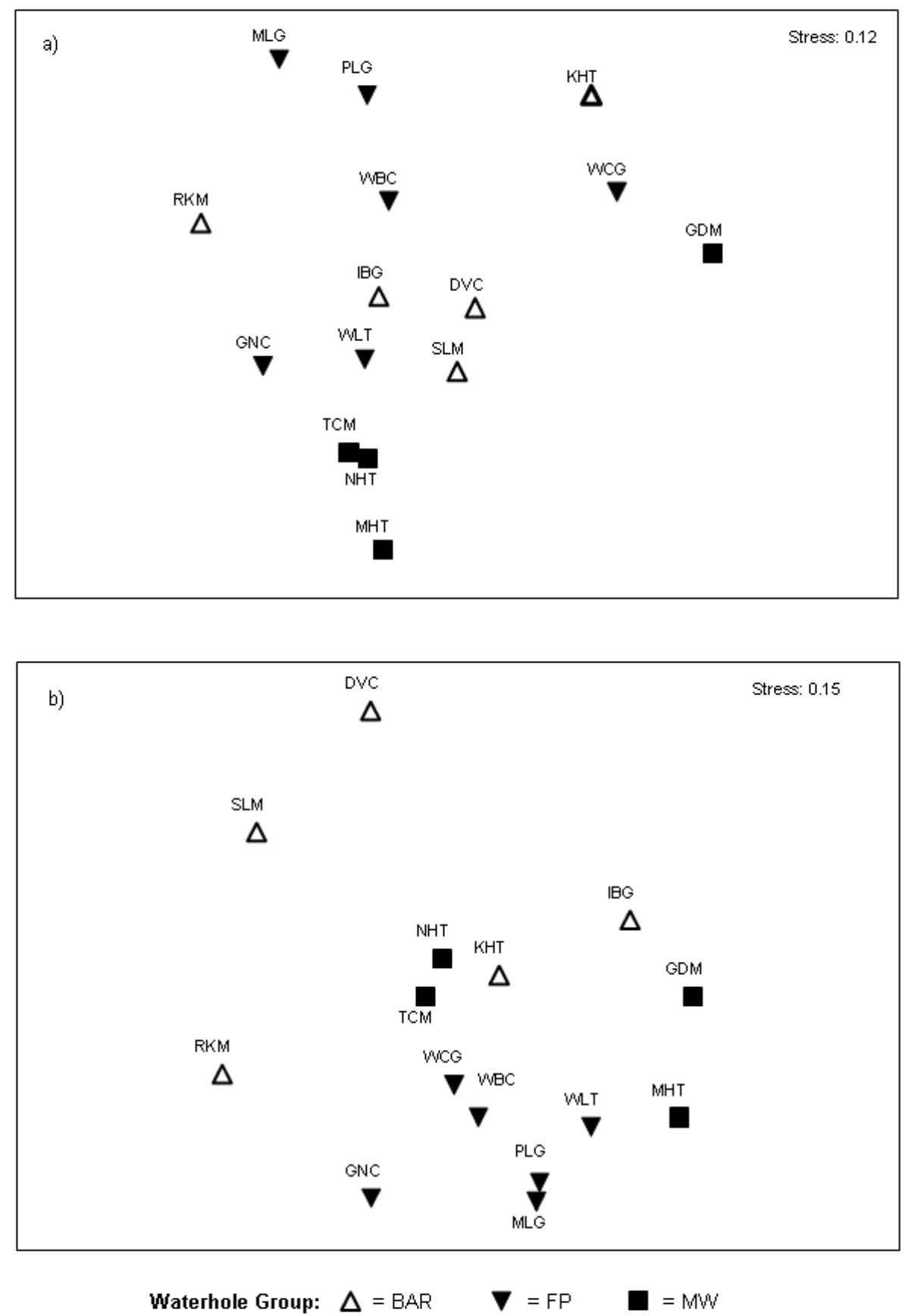

Figure 4 

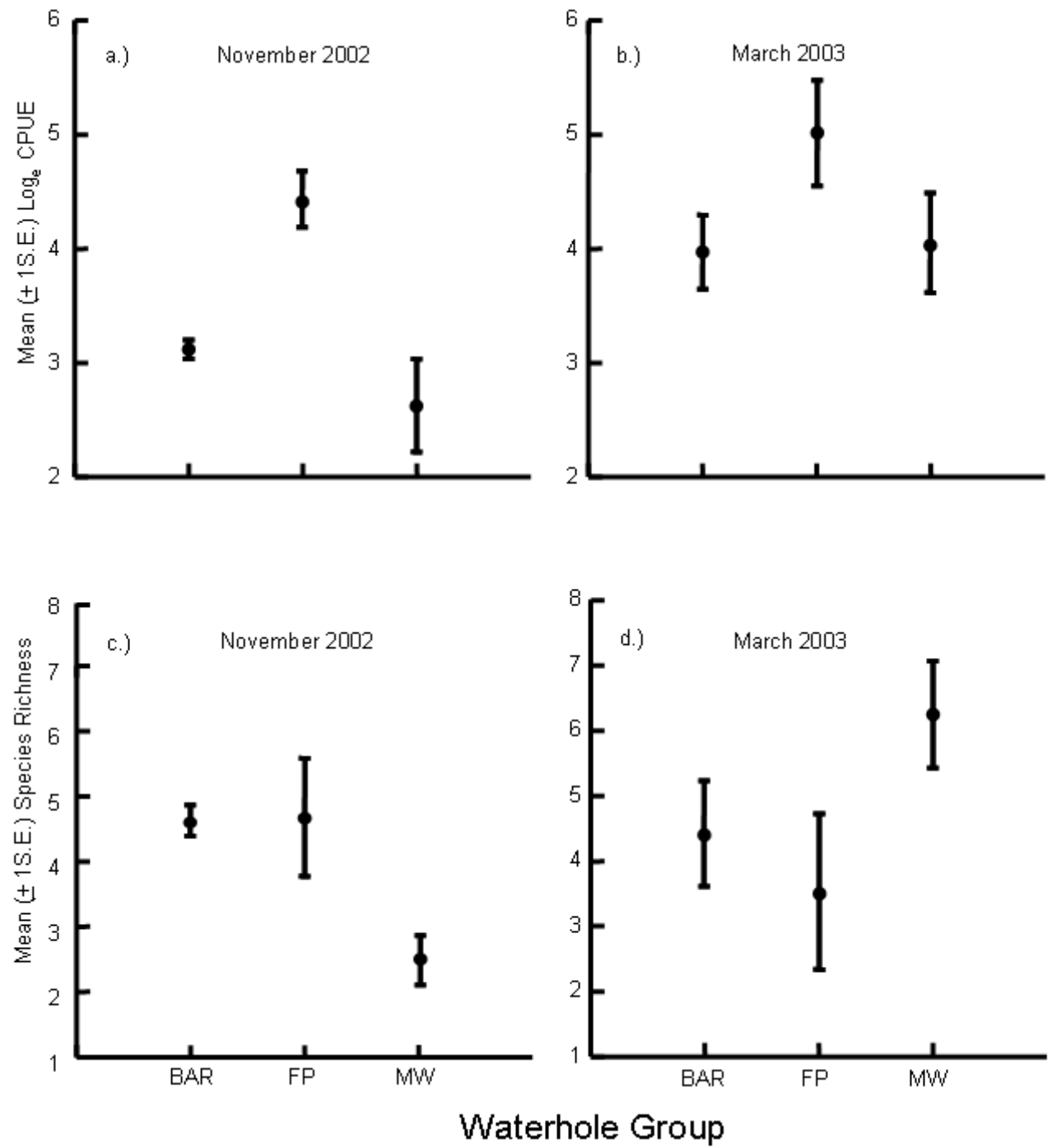

Figure 5 

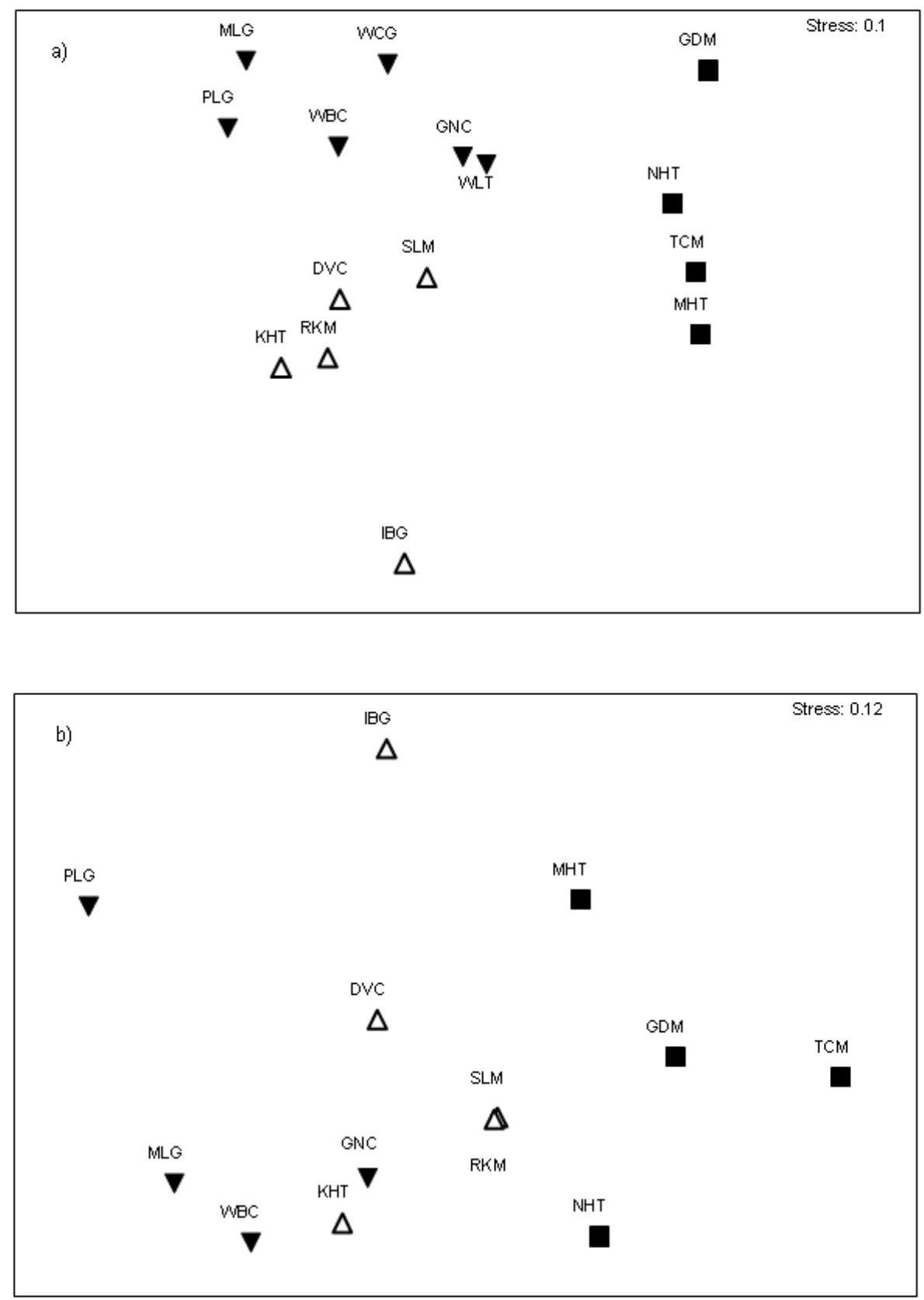

Waterhole Group: $\Delta$ = BAR $\boldsymbol{\nabla}=$ FP $\quad \square=$ MW

Figure 6 

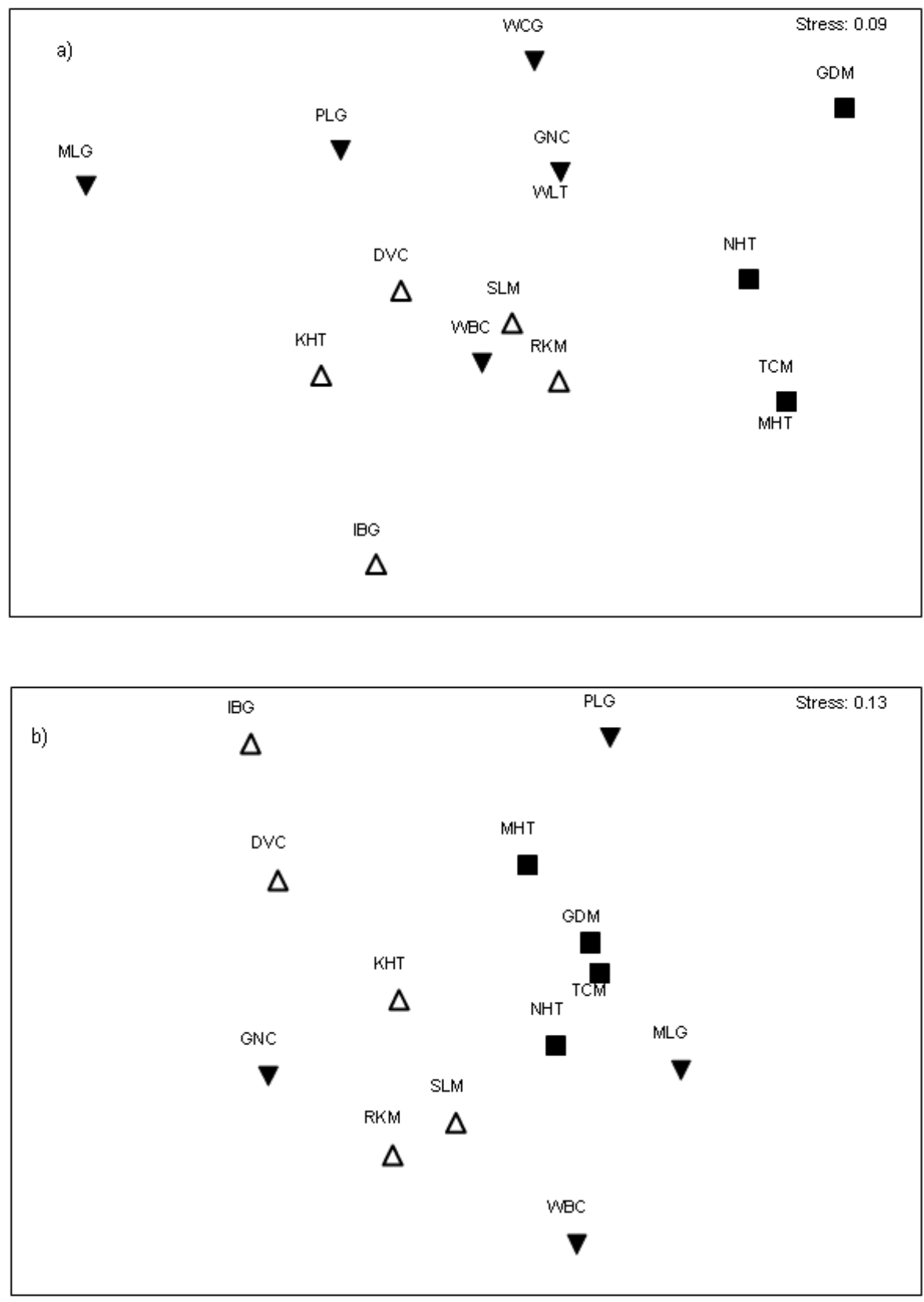

Waterhole Group: $\Delta$ = BAR $\boldsymbol{\nabla}=$ FP $\quad \boldsymbol{\square}=$ MW

Figure 7 